\title{
Lymphoid Cell Count
}

National Cancer Institute

\section{Source}

National Cancer Institute. Lymphoid Cell Count. NCI Thesaurus. Code C139064.

The determination of the amount of lymphoid cells present in a sample. 